\title{
ДОКТРИНАЛЬНА ХАРАКТЕРИСТИКА ПУБЛІЧНОЇ АДМІНІСТРАЦІї У СФЕРІ БЕЗПЕКИ ДОРОЖНЬОГО РУХУ
}

\author{
Шевченко Л. В., к. ю. н. \\ Стариий викладач кафедри \\ адміністративного права і процессу Наџіональної академї внурішніх справ
}

DOI: https://doi.org/10.31435/rsglobal_ejits/30112018/6223

\section{ARTICLE INFO}

Received 16 August 2018

Accepted 15 November 2018

Published 30 November 2018

\section{KEYWORDS}

subjects, public administration,

safety, competence,

public authority,

traffic, road accident.

\begin{abstract}
In the article the author has researched and selected the qualification groups of subjects of public administration of traffic safety, namely subjects of general competence, special competence and auxiliary competence (mediated).
\end{abstract}

Citation: Шевченко Л. В. (2018) Doktrynalna Kharakterystyka Publichnoi Administratsii u Sferi Bezpeky Dorozhnoho Rukhu. European Journal of Intelligent Transportation Systems. 1(1). doi: 10.31435/rsglobal_ejits/30112018/6223

Copyright: (C) 2018 Шевченко Л. В. This is an open-access article distributed under the terms of the Creative Commons Attribution License (CC BY). The use, distribution or reproduction in other forums is permitted, provided the original author(s) or licensor are credited and that the original publication in this journal is cited, in accordance with accepted academic practice. No use, distribution or reproduction is permitted which does not comply with these terms.

Аналіз дослідження та публікації. Дану проблематику щодо суб’єктів публічної адміністрації щодо безпеки дорожнього руху розглядали такі дослідники як В. М. Бесчастний, С. І. Будник, Б. Ю. Бурбела, М. Ю. Веселов, С. М. Гусарова, М. М. Долгополова, В. В. Доненко, В. Й. Развадовський, Т. О. Гуржій, Ю. С. Коллер, О. В. Кузьменко, В. К. Колпаков, В. Ф. Муцка, О. В. Пефтієв, Л. І. Сопільник, О. Г. Стрельченко тощо. Водночас, незважаючи на повноту чи грунтовність, узагальненість чи деталізацію авторських поглядів, з огляду на радикальні зміни у законодавстві, навіть останні з них на сьогодні не є цілковито об'єктивними.

Метою цієї статті $\epsilon$ визначення провідної ролі суб'єктів публічного адміністрування щодо безпеки дорожнього руху в сучасних умовах, а також окреслення основних напрямів вдосконалення їх діяльності.

Виклад основного матеріалу. 3 огляду на сучасний розвиток адміністративноправової доктрини актуалізується проблема публічного адміністрування сферою безпеки дорожнього руху в Україні. 3 визнанням пріоритетності утвердження та забезпечення прав людини в адміністративно-правовій науці цілком обгрунтовано здобула поширення позиція щодо запровадження сервісної концепції, відповідно до якої суб'єкти публічного управління мають якнайповніше забезпечувати права, свободи і законні інтереси фізичних та юридичних осіб. Саме крізь призму оновленого розуміння ролі адміністративного права постає завдання дослідження безпеки дорожнього руху. Актуальність проблеми забезпечення безпеки дорожнього руху не викликає сумніву. 
Погляди влади та громадянина щодо необхідності такої діяльності як важливої складової успіху трансформації відносин у цій сфері співпадають [1, с. 86].

В аваріях на автошляхах світу щорічно гине 1300000 людей, близько 50 млн. людей отримують травми, які призводять до інвалідності. Україна за рівнем смертності від ДТП посідає п’яте місце в Європі. В нашій країні щороку відбувається понад 200 тис. ДТП, 3 них 26 тис. 3 тілесними ушкодженнями. Кожна третя загибла особа молода людина віком до 29 років. За оцінками Всесвітнього банку, втрати української економіки від ДТП щорічно сягають млрд. доларів [1, с. 86].

За роки незалежності в Україні створено відповідні нормативну базу та організаційну структуру, що забезпечують безпеку дорожнього руху. 3 моменту прийняття законів та створення організаційних структур внесено численні зміни та доповнення до чинного законодавства та у структуру й функціональну спрямованість органів, які забезпечують безпеку дорожнього руху. Здійснювалися спроби законодавця як лібералізувати, так і посилити адміністративну відповідальність за порушення у цій сфері, однак суттєвих позитивних зрушень це не дало [1, с. 86].

3 метою дослідження публічного адміністрування сфери безпеки дорожнього руху необхідно грунтовно дослідити правову категорію «публічна адміністрація» та «публічна адміністрація у сфері безпеки дорожнього руху».

У здійсненні публічного адміністрування у сфері безпеки дорожнього руху беруть участь у межах своєї компетенції різні публічні органи (посадові особи). 3 цього приводу необхідно зауважити, що перехід від державоцентристських до людиноцентристських пріоритетів адміністративно-правового регулювання зумовив зміну акцентів у спрямуванні адміністративно-правового регулювання, вивів у системі суб`єктів адміністративно-правових відносин на перший план особу з іiі правами, законними інтересами, свободами. Тому, на думку В.Б. Авер'янова, першочергового перегляду сьогодні потребують існуючі відносини між публічними органами та громадянами. I це не дивно, оскільки складність справи полягає в тому, що замість домінуючої дотепер ідеології «панування» держави над людиною треба впроваджувати протилежну ідеологію «служіння» держави інтересам людини. А такий перехід можливий лише за умови дійсного запровадження передбаченого Конституцією України принципу верховенства права. За своїм змістом він вимагає підпорядкування діяльності державних інститутів потребам реалізації прав і свобод людини, забезпечення їх пріоритетності перед усіма іншими цінностями демократичної, соціальної, правової держави [2, с. 25].

Термін публічна адміністрація на законодавчому рівні на сьогоднішній день не визначений, але п. 17 ст. 4 КАСУ визначає поняття публічної служби як діяльності на державних політичних посадах, у державних колегіальних органах, професійна діяльність суддів, прокурорів, військова служба, альтернативна (невійськова) служба, інша державна служба, патронатна служба в державних органах, служба в органах влади Автономної Республіки Крим, органах місцевого самоврядування [3].

Необхідно також зазначити, що поняття публічної адміністрації не є новиною для українського права взагалі.

«Публічна адміністрація» в адміністративному праві європейських країн визначається як сукупність органів та установ, які реалізовують публічну владу шляхом ви конання законів, підзаконних нормативно-правових актів та вчинення інших дій у публічних інтересах [4, с. 173].

Ю.В. Фомін звертає увагу на те, що таке їі розуміння є актуальним і для української правової системи, звісно, з урахуванням певних національних особливостей [5, с. 39].

Ю.Л. Панейко відзначав, що основою адміністративного права $є$ те, що воно регулює організацію та діяльність публічної адміністрації [6].

Треба відзначити, що публічна адміністрація, як правова категорія, має два виміру: функціональний і організаційно-структурний. При функціональному підході - це діяльність відповідних структурних утворень по виконанню функцій, спрямованих на реалізацію публічного інтересу. Таким інтересом в українському праві визнається інтерес соціальної 
спільності, що легалізований і задоволений державою. Таким чином, наприклад, виконання публічною адміністрацією правоохоронної функції означає системну діяльність всіх структурних утворень, які мають таку функцію [7, с. 37; 8, с. 111].

При організаційно-структурному підході публічна адміністрація - це сукупність органів, які утворюються для здійснення (реалізації) публічної влади. В українському праві публічною владою визнається: а) влада народу, як безпосереднє народовладдя; б) державна влада - законодавча, виконавча, судова; в) місцеве самоврядування [9, с. 37; 10, с. 111].

Слід відзначити, що публічною владою в українському праві визнається: а) влада народу, як безпосереднє народовладдя; б) державна влада - законодавча, виконавча, судова; в) місцеве самоврядування. Відповідно до цього, в Україні публічну владу здійснюють такі органи: по-перше, Верховна Рада України (парламент), Президент України (як владний інститут), місцеві ради. Вони реалізують владу народу, що знаходить вираз у виборчих процесах; по-друге, усі органи і установи, що реалізують державну владу. Наприклад, органи виконавчої влади, суди та інші; потретє, усі органи і установи, що реалізують місцеве самоврядування. Наприклад, виконавчі комітети місцевих рад, громадські об'єднання, органи самоорганізації населення тощо. Таким чином, перелічені суб'єкти утворюють систему публічної адміністрації [9, с. 38].

Таким чином, публічна адміністрація - це система організаційно-структурних утворень, які на законних підставах набули владних повноважень для їх реалізації в публічних інтересах [11, с. 56, 12].

На сьогодні публічна адміністрація здійснюють різні функції щодо задоволення потреб людини та громадянина, однією 3 цих функцій є адміністративно-правовий захисту дитини.

Водночас, Л.О. Кожура під публічною адміністрацією розуміє систему органів виконавчої влади та органів місцевого самоврядування, підприємства, установи та організації та інші суб'єкти, наділені адміністративно-управлінськими функціями, які діють з метою забезпечення інтересів суспільства [13, с. 110].

Саме тому, на наш погляд, основним суб'єктом, на якого покладаються обов'язки щодо безпеки дорожнього руху, є тільки держава. Роль держави як головного гаранта прав і свобод людини і громадянина, в тому числі й щодо безпеки дорожнього руху, реалізується за допомогою різних правових засобів через усю систему органів державної влади.

Відповідно, вважаємо за доцільне, запропонувати визначення детермінанти «публічної адміністрації» як система суб'єктів, наділених управлінськими повноваженнями, спрямованих на реалізацію публічного інтересу.

Одночасно, темою нашого дослідження є публічна адміністрація у сфері безпеки дорожнього руху, яку не визначено ні на науковому, ні на законодавчому рівні. Саме тому назріла необхідність у дослідженні даної категорії.

Доцільно відзначити, що О. І. Стахов визначає «орган забезпечення безпеки» як державний орган чи орган місцевого самоврядування, їх системні утворення та посадових осіб, які мають право (та водночас несуть обов'язок) видавати правові акти 3 встановлення та (чи) забезпечення виконання загальнообов'язкових умов та вимог безпеки $[14$, с. 40$]$.

С. В. Селезень, Л. В. Єрофєєнко, Ю. М. Нещеретний під «суб’єктами управління транспортом» розуміють органи, організації та їхніх посадових осіб, створені у встановленому законодавством порядку спеціально для здійснення управлінських функцій, наділені правами і обов'язками, щоб своїми діями реалізовувати надані права i виконувати покладені на них обов'язки [15, с. 28-29].

В. Й. Развадовський під «суб'єктом державного регулювання транспортної системи» розуміє організаційно відокремлену складову системи органів виконавчої влади (іх посадових та службових осіб), що має державно-владні, розпорядчі, організаційні повноваження щодо здійснення завдань та реалізації функцій державної 
політики у галузі транспорту, 3 урегулюванням діяльності нормами переважно адміні $\neg$ стративного права [7, с. 225].

Л .І. Сопільник обгрунтовує, що систему суб'єктів управління у сфері забезпечення безпеки дорожнього руху утворюють державні (регіональні, галузеві) та громадські (органи місцевого самоврядування, громадські організації) суб'єкти управління [16].

М. А. Микитюком сформульовано поняття «суб'єкт владних відносин у сфері забезпечення безпеки дорожнього руху» як державний орган, що наділяється компетенцією застосування заходів державного впливу з метою забезпечення прав, свобод та законних інтересів громадян у сфері безпеки дорожнього руху [17, с. 7].

Б. Ю. Бурбело у дефініції суб'єкта забезпечення безпеки дорожнього руху бачить лише перерахування більш-менш загальних або конкретних заходів (функцій), у яких цей суб'єкт реалізує свій адміністратив $\neg$ но-правовий статус (сукупність прав та обов'язків), якими є: орга ᄀнізації дорожнього руху; підготовки та допуску до участі у дорожньому русі водіїв транспортних засобів і тощо [18, с. 77].

Безумовно, це не є вичерпним переліком поглядів на зазначену дефініцію.

У визначенні суб’єкта адміністративно-правової профілактики дитячого дорожньо-транспортного травматизму (одного з напрямів забезпечення БДР) М. Ю. Веселов робить акцент на таких рисах: а) ними можуть бути державні та недержавні структури; б) характер зв'язків між ними - взаємодія або підпорядкування [19, с. 94].

Актуалізація проблеми публічного права викликана низкою причин, серед яких виділяються: необхідність проведення правової реформи; глибока зміна багатьох галузей права; розвиток структури і системи правових галузей; посилення ролі держави в реалізації планів соціально-економічного розвитку країни [25, с. 74]. Крім органів, які представляють державний сектор, публічне право також поширює свою дію і на сферу організації та функціо $\neg$ нування недержавних установ, зокрема органів місцевого самоврядування, які не входять до вищеназваного сектору.

Водночас, публічною адміністрацією у сфері безпеки дорожнього руху слід визначити систему суб'єктів, наділених публічно-владними повноваженнями, які за допомогою правових засобів забезпечують безпеку дорожнього руху.

Б. Ю. Бурбело, А. П. Головін, С. І. Саєнко класифікують суб'єкти забезпечення безпеки дорожнього руху на підставі ознаки наявності в суб'єкта забезпечення безпеки дорожнього руху публічно-владних повноважень. У цьому разі серед суб'єктів забезпечення безпеки дорожнього руху слід розрізняти, з одного боку, органи державної влади та органи місцевого самоврядування, а з іншого - суб'єктів, що не наділені публічно-владними повноваженнями [18].

Так, під ознаки суб'єктів забезпечення безпеки дорожнього руху, що мають публічно-владні повноваження, підпадають такі суб'єкти адміністративного права: Верховна Рада України; Президент України; Кабінет Міністрів України; центральні органи державної виконавчої влади, що мають повноваження у сфері забезпечення безпеки дорожнього руху, та їх територіальні підрозділи; місцеві державні адміністрації, їх управління та відділи; прокуратура України; суди загальної юрисдикції; органи місцевого самоврядування [18].

Також ці автори здійснили класифікацію органів державної виконавчої влади, що мають повноваження у сфері забезпечення безпеки дорожнього руху, розрізнили суб'єктів забезпечення безпеки дорожнього руху 3 загальною компетенцією від суб'єктів забезпечення безпеки дорожнього руху зі спеціальною компетенцією. До суб'єктів із загальною компетенцією віднесли органи державної виконавчої влади, повноваження яких поряд із іншими сферами суспільного життя поширюються на сферу забезпечення безпеки дорожнього руху: Кабінет Міністрів України; Міністерство внутрішніх справ України; Міністерство інфраструктури України; Міністерство оборони України; Міністерство охорони здоров'я України; Міністерство освіти і науки України; Міністерство аграрної політики та продовольства України; Міністерство 
регіонального розвитку, будівництва та житлово-комунального господарства України; Міністерство юстиції України; Державна служба України з надзвичайних ситуацій; Державна казначейська служба України; Державна виконавча служба України; Державна фіскальна служба України; місцеві державні адміністрації тощо [18].

В. Й. Развадовським запропоновано класифікацію єдиної системи суб'єктів адміністративно-правового регулювання транспортної сфери, в якій він виділяє інституційні, звичайні та спеціальні суб'єкти адміністративно-правового регулювання. До інстутиційних суб'єктів регулювання ним віднесено: Верховну Раду України, яка ухвалює закони; Президента України, який видає укази і розпорядження, зокрема 3 питань регулювання діяльності транспортної сис ᄀтеми; органи місцевого самоврядування. Звичайними суб'єктами адміністративно-правового регулювання транспортної сфери є: Міністерство транспорту України та його органи (напри ᄀклад, Укравгодор, Укрзалізниця та ін.), міністерства, відомства, комітети, інспекції, місцеві органи виконавчої влади.

До спеціальних суб’єктів адміністративно-правового регулювання віднесено ДАІ МВС України, військову інспекцію безпеки дорожнього руху Збройних Сил України та інші формування, службу безпеки дорожнього руху Держкомкордону України, Службу правопорядку у Збройних Силах України, громадські формування. У складі системи суб'єктів адміністративно-правового регулювання транспортної сфери особливе місце посідають суб'єкти державного управління, якими є органи виконавчої влади. За ознакою компетенції щодо здійснення державно-управлінської діяльності у сфері транспорту ними є: Кабінет Міністрів України; Міністерство інфраструктури України (його територіальні органи); урядові органи державного управління, які можуть бути створені у складі Міністерства інфраструктури України (департаменти, служби, інспекції (які не входять до складу Міністерства інфраструктури України); місцеві державні адміністрації. У процесі здійснення управлінської діяльності органи державного управління (у межах компетенції, встановленої чинним законодавством) взаємодіють 3 органами місцевого самоврядування, громадськими організаціями, окремими громадянами» [20, с. 252-253]

Т. О. Гуржій крім зазначених суб’єктів забезпечення дорожнього руху він відносить Президента України, Раду національної безпеки та оборони України, Управління безпеки дорожнього руху («спадкоємець» Державтоінспекції), органів місцевого самоврядування [21].

Завдяки напрацюванням цих авторів адміністративно-правова наука має майже повну картину суб'єктів публічно-правового забезпечення безпеки дорожнього руху та суб'єктів, що не наділені публічно-владними повноваженнями. У зазначених працях достатньо повно надано системно-структурну характеристику всім суб'єктам публічного адміністрування у сфері забезпечення безпеки дорожнього руху, визначено основні структурні та функціональні вади, запропоновано власні погляди щодо пріоритетних напрямків удосконалення організаційно-правових засад функціонування загальнодержавної системи забезпечення безпеки дорожнього руху та налагодження взаємодії іiі суб'єктів [19, с. 118]; запропоновано комплекс організаційно-правових заходів, спрямованих на побудову управлінської вертикалі у сфері БДР; перерозподіл повноважень та чітке розмежування компетенції суб'єктів галузевого управління, налагодження між ними ефективної взаємодії, вдосконалення механізмів контролю за ïх діяльністю [22, с. 19-20]. На основі аналізу принципів, функцій та методів управління системою забезпечення безпеки дорожнього руху зроблено висновок, що в складі зазначених понять слід виділити організаційні принципи побудови даної системи i організаційні принципи іiі функціонування, організаційні функції та організаційні методи управління. Встановлено, що реалізація таких організаційних засад управління надасть можливості чіткої та ефективної побудови та функціонування загальнодержавної системи забезпечення безпеки дорожнього руху» [23, с. 13]. Крім того, сформульовано рекомендації щодо покращення взаємодії суб'єктів забезпечення 
безпеки дорожнього руху у напрямах: a) інформаційно-аналітичної роботи; б) забезпечення обміну інформацією між державними органами, що належать до системи забезпечення безпеки дорожнього руху» [20, с. 14], виявлено, що наявність ознаки цілісності управління визначає необхідність поєднання в єдину систему суб'єктів адміністративно-правового регулювання» [24]. За словами дослідників, «багатогалузевий характер сфери забезпечення безпеки дорожнього руху визначає необхідність і високу значущість управлінського впливу з боку держави для досягнення необхідних результатів» [25, с. 144].

На сьогоднішній день, на наш погляд, відповідно до ієрархічної конструкції систему публічної адміністрації безпеки дорожнього руху в Україні складають такі суб'єкти, які наділені публічно-владними повноваженнями, а саме: суб'єкти загальної компетенції, спеціальної компетенції та допоміжної компетенції (опосередкованої). До загальної компетенції відноситься: Верховна Рада України, Президент України, вищі органи виконавчої влади - Кабінет Міністрів України, місцеві органи виконавчої влади та місцеве самоврядування; до спеціальної компетенції належать: центральні органи виконавчої влади - Міністерство інфраструктури України; Міністерство внутрішніх справ України; Державна служба України з безпеки на транспорті; Державна служба України з надзвичайних ситуацій; Державне агентство автомобільних доріг України; Національна поліція України; Управління безпеки дорожнього руху; до допоміжної компетенції віднесено наступні суб'єкти: Міністерство молоді та спорту України; Міністерство оборони України; Міністерство освіти і науки України; Міністерство охорони здоров'я України; Міністерство регіонального розвитку, будівництва та житлово-комунального господарства України; Міністерство фінансів України; Міністерство юстиції України; Державна казначейська служба України; Державна міграційна служба України; Державна служба статистики України; Державна служба фінансового моніторингу України; Державна фіскальна служба України тощо.

Водночас, до суб'єктів забезпечення безпеки дорожнього руху, які не мають публічно-владних повноважень, доцільно віднести власників дорожньої техніки, учасників дорожнього руху, а також установи, підприємства та організації будь-якої форми власності, діяльність яких пов'язана 3 попередженням причин аварійності та зниженням тяжкості наслідків ДТП, а саме: а) учасники дорожнього руху - водії та пасажирів транспортних засобів, пішоходів, погоничів тварин та велосипедистів; б) власників транспортних засобів фізичних та юридичних осіб; в) підприємства виробники автомобілів та інших колісних транспортних засобів, деталей, частин, вузлів та агрегатів до них; г) підприємства, що надають послуги з технічного обслуговування, переобладнання, перевірки технічного стану та ремонту автомобілів та інших колісних транспортних засобів; д) власників автомобільних доріг; е) державні, комунальні та приватні підприємства, які здійснюють проектування, виготовлення (будівництво), обладнання, експлуатацію, обслуговування чи ремонт автомобільних доріг; є) підприємства, що надають послуги з перевезень пасажирів та вантажів автомобільним транспортом; ж) підприємства, що надають послуги 3 паркування автомобілів; 3) підприємства, що надають послуги з евакуації транспортних засобів; і) навчальні заклади 3 підготовки водіїв; к) медичні установи, які надають допомогу постраждалим у ДТП, здійснюють взаємодію з органами державної влади щодо проведення медичних оглядів водіїв та кандидатів у водії, організаційно та методично забезпечують таку діяльність; л) страхові організації, що здійснюють страхування у сфері дорожнього руху ризиків, пов’язаних $з$ ДТП, та координацію такої діяльності; м) громадські організації з захисту прав водіїв та власників автотранспортних засобів, пропаганди безпеки дорожнього руху та сприяння організації перевезень (Всеукраїнська спілка автомобілістів, Міжнародна спілка автомобільного транспорту (ІК.У), Асоціація міжнародних автомобільних перевізників України, Союз перевізників України, Професійна спілка таксистів України та інші); н) громадські організації з автомобільного спорту та мотоспорту (Автомобільна Федерація України (РАЦІ) та іï місцеві осередки, автомобільні спортивні клуби, мотоклуби) [19, с. 83-85]. 


\section{ЛІТЕРАТУРА}

1. Доненко В. В. Щодо системи публічного адміністрування безпеки дорожнього руху / Доненко В. В. // Право і суспільство № 12. 2012. С. 86-92.

2. Авер'янов В. Б. Адміністративна реформа і правова наука / В. Б. Авер'янов // Право України. 2002. № 3 C. 20-27.

3. Кодекс адміністративного судочинства від 06 лип. 2005 р. № 2747-4 (Із змінами, внесеними згідно із Законом України № 2234-VIII від 07 груд. 2017 року) // Офіційний вісник України - 2005. - №32. - Ст. 1918.

4. Колпаков В. К. Адміністративне право - чинник правової держави / В. К. Колпаков II Вісник Луганського державного університету внутрішніх справ імені Е.О. Дідоренка. Спеціальний випуск № 3 «Розвиток держави і права в сучасних умовах: досвід, реалії, перспективи». Луганськ, 2009. С. 171-182.

5. Фомін Ю. В. Органи внутрішніх справ України в системі публічної адміністрації: адміністративно-правові засади : рукопис дис. ... канд. юрид. наук : спец. 12.00.07 «Адміністративне право і процес; фінансове право; інформаційне право» / Ю. В. Фомін ; Харківський нац. ун-т внутр. справ. Х., 2012. 227 с.

6. Панейко Ю. Л. Теоретичні основи самоврядування / Ю. Л. Панейко. Л.: Літопис, 2002. 196 с.

7. Курс адміністративного права України : підруч. / Авторський колектив / Коваленко В. В. Колпаков В. К., Кузьменко О. В. К. : Юрінком Інтер, 2012. 875 с.

8. Колпаков В., Мацелик Т. Предмет адміністративного права: оновлення парадигми // Право України. 2010. № 8. С. 110-115.

9. Курс адміністративного права України : підруч. / Колпаков В. К., Кузьменко О. В., Пастух І. Д., Сущенко В. Д. - 2-ге вид. перероб. і допов. К.: Юрінком Інтер, 2013. 872 с.

10. Колпаков В., Мацелик Т. Предмет адміністративного права: оновлення парадигми // Право України. 2010. № 8. С. 110-115.

11. Адміністративна відповідальність : курс лекцій / О. В. Кузьменко, І.Д Пастух, . [та ін.]. К.: Юрінком Інтер, 2016. 568 c.

12. Адміністративна відповідальність та провадження в справах про адміністративні правопорушення : навч. посіб. / О. В. Кузьменко, М. В. Плугатир, І. Д. Пастух та інші. К. : «Центр учбової літератури». 2017. $388 \mathrm{c}$.

13. Кожура Л. О. Адміністративно-правовий захист бездомних осіб і безпритульних дітей: дис... на здоб. наук. ступ. канд. юрид. наук: спец.: 12.00.07 - адміністративне право і процес; фінансове право; інформаційне право. К. 2013. 247 с.

14. Стахов А. И. Органи обеспечения безопасности как субьектьі административного права / А. И. Стахов II Вестник Московского университета МВД России. 2007. № 2, С. 40-43.

15. Транспортне право: навчально-методичний посібник / С. В. Селезень, Л. В. Срофєєнко, Ю. М. Нещеретний; М-во освіти і науки України, Харк. нац. автомоб.-дор. ун-т. Х.: ХНАДУ, 2007. 263 с.

16. Сопільник Л. І. Теорія та практика адміністративно-правового регулювання організації безпеки дорожнього руху в Україні : рукопис. дис... д-ра юрид. наук: 12.00.07 «Адміністративне право і процес; фінансове право; інформаційне право» / Л.І. Сопільник ; Харківський. нац. ун-т внутр. справ. Х., 2012. 422 с.

17. Микитюк М. А. Владні повноваження Державної автомобільної інспекції Міністерства внутрішніх справ України: проблеми теорії та практики реалізації у сфері забезпечення безпеки дорожнього руху : автореф. дис... канд. юрид. наук : спец. 12.00.07 «Адміністративне право і процес; фінансове право; інформаційне право» / М. А. Микитюк ; Львів, держ. ун-т внутр. справ. Л., 2008. 20 с.

18. Бурбело Б. Ю. Організаційно-правові засади взаємодії суб'єктів забезпечення безпеки дорожнього руху : рукопис дис... канд. юрид. наук : 12.00 .07 спец. «Адміністративне право і процес; фінансове право; інформаційне право» / Б. Ю. Бурбело ; Луганський, держ. ун-т внутр. справ ім. Е. О. Дідоренка. Л., 2011. 229 с.

19. Веселов М. Ю. Адміністративно-правова профілактика дитячого дорожньо-транспортного травматизму в Україні : монографія / М. Ю. Веселов ; ДЮІ ЛДУВС ім. Е. О. Дідоренка. - Донецьк : Видавничий дім «Норд-Прес», 2011. 219 с.

20. Развадовський В. Й. Державне регулювання транспортної системи України (адміністративноправові проблеми та шляхи їх розв'язання): рукопис, дис... д-ра юрид. наук : спец. 12.00.07 «Адміністративне право і процес; фінансове право; інформаційне право» / В. Й. Развадовський ; Харків, нац. ун-т внутр. справ. Х., 2004. 508 с.

21. Гуржій Т. О. Державна політика безпеки дорожнього руху - теоретико-правові та організаційні засади : дис. ... докт. юрид. наук : спец. 12.00.07 «Адміністративне право і процес; фінансове право; інформаційне право» / Т. О. Гуржій. К., 2011. 551 с. 
22. Долгополова М. М. Управління загальнодержавною системою забезпечення безпеки дорожнього руху : рукопис дис... канд. юрид. наук : спец. 12.00.07 «Адміністративне право і процес; фінансове право; інформаційне право» / М. М. Долгополова ; Харків, нац. ун-т внутр. справ. Х., 2003. 182 с.

23. Муцко В. Ф. Адміністративно-правове регулювання безпеки дорожнього руху в Україні : рукопис дис. ... канд. юрид. наук : спец. 12.00.07 «Адміністративне право і процес; фінансове право; інформаційне право» / В. Ф. Муцко ; Нац. ун-т біоресурсів і природокористування України. К., 2011. $198 \mathrm{c.}$

24. Бесчастний В. М. Державне управління в сфері безпеки дорожнього руху : монографія / В. М. Бесчастний. Донецьк : ДЮІ ЛДУВС ім. Е. О. Дідоренка, 2011. 473 с.

25. Пефтієв О. В. Адміністративно-правові засади функціонування автомобільного транспорту : рукопис дис. ... канд. юрид. наук : спец. 12.00.07 «Адміністративне право і процес; фінансове право; інформаційне право» / О.В. Пефтієв ; Донецький юрид. інститут ЛДУВС ім. Е. О. Дідоренка-Д., 2011. 244 с. 